\title{
Ecophysiological capability of Marenzelleria populations inhabiting North Sea estuaries: an overview
}

\author{
Doris Schiedek \\ Institut für Ostseeforschung Warnemünde, Seestrasse 15, D-18119 Rostock, Germany
}

\begin{abstract}
The metabolic responses of Marenzelleria cf. wireni, a newly established polychaete worm within North Sea estuaries, to various kinds of environmental stress are summarised. With respect to salinity, $M$. cf. wireni is able to deal with variations within a wide range. In the process of osmotic acclimation, free amino acids are involved. The major amino acid in terms of osmotic effector is glycine, followed by alanine. Under severe hypoxia, $M$. cf. wireni switches to an anaerobic metabolism, but at a very low oxygen partial pressure $(<3 \mathrm{kPa})$, which indicates efficient utilisation of oxygen. Anderobic energy production occurs predominantly via the succinate-propionate pathway. When exposed to hydrogen sulphide, $M$. cf. wireni is able to cope with high sulphide concentrations (up to $3 \mathrm{mmol}^{-1}$ ), but the pattern of end products of the anderobic energy metabolism changes. In terms of sulphide tolerance, $M$. cf. wireni probably is even better adapted than other, indigenous polychaetes. However, in comparison with the sibling species Marenzelleria viridis, which appeared at the same time in European waters but mainly inhabits the coastal inlets of the Baltic Sea in high numbers, the metabolic capabilities of $M$. cf. wireni seem to be more limited at higher sulphide concentrations $\left(>1 \mathrm{mmol} \mathrm{l}^{11}\right)$. This might have an influence on the distribution pattern of the two sibling species.
\end{abstract}

\section{INTRODUCTION}

In the late 1970s and early 1980s, an unknown burrow-living polychaete worm was discovered in several North Sea estuaries and coastal inlets of the Baltic (Atkins et al., 1987; Elliot \& Kingston, 1987; Bick \& Burckhardt, 1989; Essink \& Kleef, 1993). During the next 10 years, it spread rapidly and became an important member of the macrobenthic community within northwest European coastal waters (Essink \& Kleef, 1993; Bick \& Zettler, 1997; Zettler, 1997; Essink et al., 1998). Since this worm very much resembled the spionid Marenzelleria viridis, which originates from the east coast of North America, it was assigned to this species.

Coastal areas and estuaries are known to be environments where conditions may fluctuate widely and are not highly predictable. It is obvious that such habitats can only be invaded by species capable of responding to physiological challenges imposed by highly variable physical and chemical environmental conditions. Responses to environmental fluctuations, however, cannot be restricted to a mere passive tolerance, but also include biochemical and physiological features. In order to elucidate whether the nonindigenous worm has specific ecophysiological abilities to cope with environmental

(. Biologische Anstalt Helgoland, Hamburg 
stress, several laboratory studies were conducted. The present paper aims to give an overview of the results obtained on the metabolic responses of Marenzelleria ssp. The main focus is on the North Sea populations from the Ems and the Tay estuary. These populations are at present described as type I (Bastrop et al., 1997) or Marenzelleria cf. wireni (Bick \& Zettler, 1997).

\section{METABOLIC RESPONSE TO SALINITY VARIATIONS}

Most North Sea estuaries are subjected to a semi-diumal tidal regime, with a tidal range of up to some metres and large fluctuations in salinity. In the Tay estuary (Scotland), for instance, salinity covers a range between 20\% and 6\%, (Williams \& West, 1975 ) and in the Ems estuary (The Netherlands) salinity varies between $25 \%$ and $5 \%$ (Essink et al., 1998). Therefore, maintaining the proper salt and water balance of cells and body fluids is one of the greater challenges benthic organisms have to face when inhabiting such an environment successfully.

Many marine invertebrates are osmoconformers. When transferred from one salinity regime to another, they will gain or lose water along the osmotic gradient set up by the transfer. In order to counteract the swelling or shrinking and prevent osmotic lysis they have to perform active isosmotic volume regulation. Since the discoveries of Florkin (1956, 1962) and Duchateau-Bosson \& Florkin (1961) free amino acids have been known as a group of organic compounds which act as intracellular osmotic effectors. Their involvement in osmoregulation has been shown for several marine invertebrates (Oglesby, 1978; Gilles, 1987).

In $M$. cf. wireni, too, free amino acids take part in the regulation of intracellular volume. Their content varies between 60 and $250 \mu \mathrm{mol} \mathrm{g} \mathrm{g}^{-1}$ dry wt and is strongly related to the salinity of the pore water (Fig. 1). When experimentally acclimated to various salin-

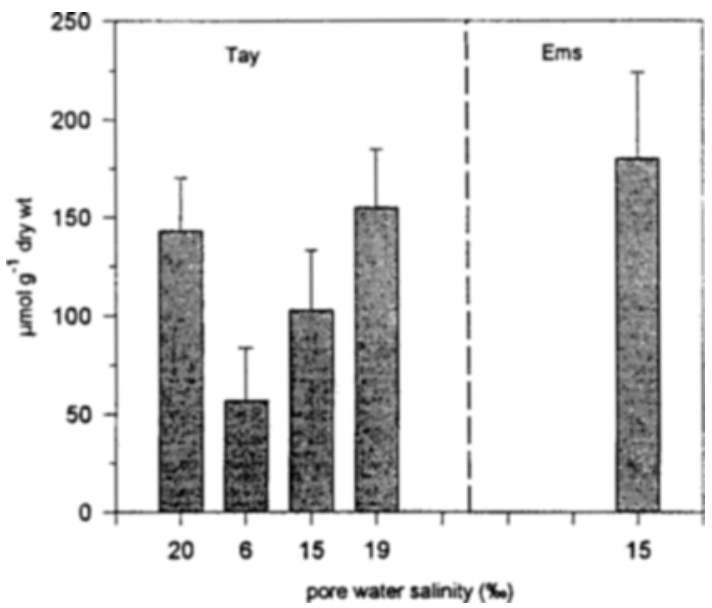

Fig. 1. Marenzelleria cf. wireni. Total amount of major free amino acids ( $\mu \mathrm{mol} \mathrm{g}^{-1}$ dry wt) in worms from the Tay (Scotland) and the Ems estuary (The Netherlands) under various environmental salinity regimes. Mean $\pm S E M, n=8$ 


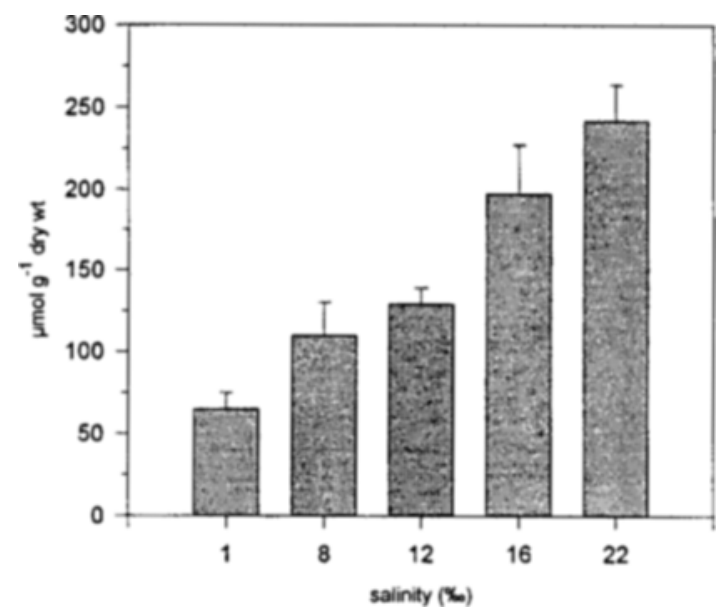

Fig. 2. Marenzelleria cf. wireni. Total amount of major free amino acids ( $\mu$ mol $\mathrm{g}^{\prime} \mathrm{dry}$ wt) after a 2week acclimation. Mean \pm SEM, $n=8$

ity regimes (for experimental details see Schiedek, 1997b) the relationship between salinity and the content of free amino acids is even more pronounced (Fig. 2). Nevertheless, these concentrations are clearly lower than in other euryhaline polychaetes. In the lugworm Arenicola marina, for instance, the content of free amino acids in the body wall musculature amounts to about $1100 \mu \mathrm{mol} \mathrm{g}^{-1}$ dry wt in full-strength sea water (Schöttler et al., 1990). After osmotic acclimation to a salinity of $12 \%$, it is reduced to about $500 \mu \mathrm{mol} \mathrm{g}{ }^{-1}$ dry wt (Schiedek \& Schöttler, 1989). A somewhat similar content

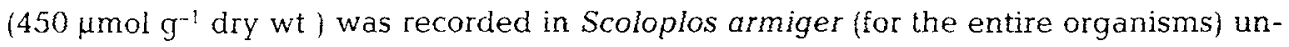
der this salinity regime (Schiedek \& Schöttler, 1989). In the ragworm Hediste diversicolor, the intracellular content of free amino acids in the tissues is clearly lower under these conditions (200 $\mu \mathrm{mol} \mathrm{g}^{-1}$ dry wt), but still higher than in $\mathrm{M}$. cf. wireni $\left(130 \mu \mathrm{mol} \mathrm{g}^{-1}\right.$ dry wt; Fig. 2). This indicates that the importance of free amino acids as osmotic effectors differs among polychaete species, but the pool size of amino acids does not always imply salinity tolerance. The ragworm $H$. diversicolor, for instance, is known to inhabit not only marine habitats (salinity $32 \%$ ), but also brackish waters down to almost fresh water (Hohendorf, 1963). At salinities below 14\% it performs osmoregulation, whereas at higher salinities it reacts as an osmoconformer (Hohendorf, 1963). Measurements of the osmolarity of the coelomic fluids in $M$. cf. wireni have revealed that at salinities below $10 \%$ it is also able to hyperregulate, whereas at higher salinities the coelomic fluids are almost isosmotic to the ambient medium (Bastrop et al., 1997). This demonstrates that not only free amino acids but also other mechanisms are involved in osmotic acclimation.

The amino acids taking part in intracellular osmoregulation vary from species to species, but usually appear to be a combination of non-essential amino acids, such as glycine, alanine, proline, glutamate, taurine and occasionally aspartate or glutamine (Oglesby, 1978; Gilles, 1987). In M. cf. wireni, glycine represents the major amino acid in terms of an osmotic effector, followed by alanine, irrespective of the ambient salinity (Fig. 3). In the Marenzelleria populations that successfully invaded the coastal waters of 


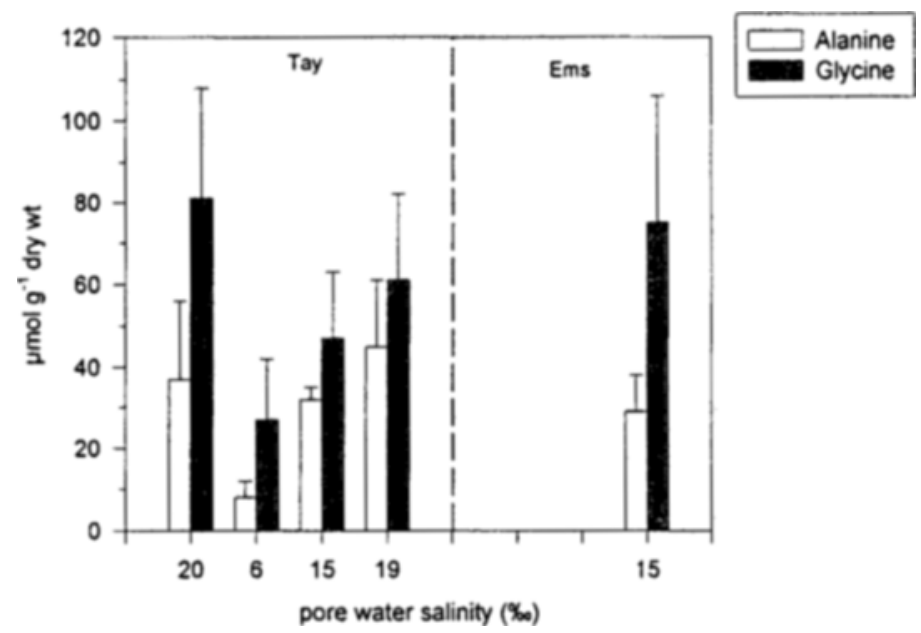

Fig. 3. Marenzelleria cf, wireni. Content of free amino acids, glycine and alanine ( $\mu$ mol $\mathrm{g}^{-1} \mathrm{dry}$ wt) in worms from the Tay and Ems estuary under various environmental salinity regimes. Mean \pm SEM, $n=8$

the Baltic Sea (M. viridis), not glycine but alanine was the most important amino acid when the worms were experimentally acclimated to a salinity greater than $10 \%$ (Schiedek, 1997b). The leading role of alanine at higher salinities is rather exceptional. In other marine polychaete species, either glycine is the favoured amino acid, as in $M$. cf. wireni, juvenile Arenicola marina (Schiedek \& Schöttler, 1991), Neanthes succinea and Leonereis culveri (König et al., 1981), or both, alanine and glycine have nearly the same value, as in $H$. diversicolor, even after acclimation to a salinity below $10 \%$ (Hülsmann et al., 1991). However, in $H$. diversicolor, a further amino acid, proline, is of importance for osmotic adaptation (Hülsmann et al., 1991). The physiological function of the increased alanine content in $M$. viridis at higher salinities is not clear at present, but the two sibling species evidently differ in their metabolic response during acclimation to salinities above $10 \%$. In the coastal inlets of the Baltic, salinity usually covers the range 0.5-10\%. From taxonomic studies (Bick \& Zettler, 1997) and population genetic analysis (Bastrop et al., 1997) it is suggested that $M$. cf. wireni (type I) colonise habitats with a higher salinity and/or those where salinity tends to fluctuate considerably (North Sea estuary), whereas $M$. viridis predominantly settles in oligohaline to mesohaline areas (such as the Baltic).

Despite the differences in the distribution pattern and the importance of single amino acids, both Marenzelleria species are able to deal with a wide range of salinity regimes when experimentally exposed. In $M$. viridis it ranges from $0.5 \%$ o up to $30 \%$ (Bochert, 1997) and in $M$. cf. wireni from 0.5\% to 32\% (Schiedek, unpublished data). However, with regard to reproduction and development, environmental salinity seems to have an influence. For M. viridis (Baltic Sea) it was shown that males and females failed to reach maturity within 5 months at a salinity $>25 \%$ and gametes were significantly less mature at a salinity of $30 \%$ (Bochert, 1997). Furthermore, differences in the 
spawning season between $M$. cf. wireni (spring) and $M$. viridis (autumn) are obvious (Essink \& Kleef, 1993; Bochert, 1997). Since no experiments have been performed it can only be speculated whether these differences are due to additional stress caused by fluctuations in salinity or the tidal regime within the North Sea estuary. Considerating the different origins of the two sibling species (Bastrop et al., 1997), it is also likely that the differences in the reproduction period are genetically determined.

\section{ENERGY PRODUCTION AT LOW OXYGEN CONCENTRATIONS}

The tidal rise and fall of the sea not only causes fluctuations in salinity, but also restricts the availability of oxygen to sediment-living organisms. In such periods of environmentally induced hypoxia, most benthic species therefore are not capable of taking up oxygen at a sufficient rate in order to meet their energy requirements. As a result, many marine invertebrates have to switch to an anaerobic energy metabolism (for review see Schöttler \& Bennet, 1991; Grieshaber et al., 1994).

In $M$. cf. wireni, anaerobic energy production started at a very low oxygen partial pressure $(<3 \mathrm{kPa}$ ), indicating efficient utilisation of oxygen (Schiedek, 1997a), probably because of the specific morphology of the worms. As they are long and thin, they have a relatively large surface area to volume ratio which supports oxygen transport by means of diffusion even at low partial pressure. During severe hypoxia, energy production occurs via the succinate-propionate pathway and via anaerobic glycolysis. The latter is terminated by octopine (Schiedek, 1997a). The formation of octopine or other opines (e.g. strombine or alanopine) instead of lactate is very common in marine invertebrates (Grieshaber \& Kreutzer, 1986). However, in polychaetes predominantly strombine or alanopine are formed during environmental anaerobiosis, whereas octopine is more typical for molluscs (Grieshaber \& Kreutzer, 1986; Grieshaber et al., 1994). Concerning the anaerobic energy production in total, glycolysis appears to be of only minor importance in $M$. cf. wireni, because the amount of octopine accumulated is relatively low (about $1 \mu \mathrm{mol} \mathrm{g}{ }^{-1}$ dry wt). In the catworm Nephtys hombergi, for example, about $25 \mu \mathrm{mol} \mathrm{g}{ }^{-1}$ dry wt of glycolytic end products (strombine and alanopine) are accumulated within 24 h of anaerobiosis (Arndt \& Schiedek, 1997). In the ragworm $H$. diversicolor, D-lactate amounts to $70 \mu \mathrm{mol} \mathrm{g} \mathrm{g}^{-1}$ dry wt (Schöttler et al., 1990). The differences in the importance of glycolysis within the three polychaete species might reflect their lifestyle. The predators $H$. diversicolor and $N$. hombergi are very active animals which may require energy rather instantaneously. Glycolysis offers such an opportunity. For the suspension feeder $M$. cf. wireni, living in a permanent burrow, short-term energy production via anaerobic glycolysis does not appear to confer any particular advantage.

In contrast to other marine polychaetes, $M$. cf. wireni switches to an anaerobic energy production using the succinate-propionate pathway more or less directly after the onset of anoxia. The short-chain fatty acid propionate, an important end product of anaerobiosis (Schöttler \& Bennet, 1991), is already detectable after $3 \mathrm{~h}$ of experimental anoxia (Schiedek, 1997a).

During prolonged anaerobic conditions, the breakdown of glycogen is the main source of energy production. The glycogen stored in the tissues of marine invertebrates can account for as much as $35 \%$ of the animal's dry weight (De Zwaan and Zandee, 
Table 1. Glycogen content ( $\mu \mathrm{mol}$ glycosyl units $\mathrm{g}^{\prime}$ dry wt) in Marenzelleria spp. and other marine polychaetes. $n=6-8$

\begin{tabular}{|c|c|c|c|}
\hline & North Sea & Baltic Sea & \\
\hline Marenzelleria viridis & & $197 \pm 48$ & Schiedek, 1997a \\
\hline Marenzelleria cf. wireni & $105 \pm 36$ & & Schiedek, 1997a \\
\hline Arenicola marina (juvenile) & $158 \pm 48$ & & Schiedek \& Schöttler, 1990 \\
\hline Scoloplos armiger & $121 \pm 19$ & & Schöttler \& Grieshaber, 1988 \\
\hline H. diversicolor & $411 \pm 74$ & $156 \pm 81^{\circ}$ & $\begin{array}{l}\text { Schöttler et al, } 1990 \\
\text { - Schiedek, unpublished data }\end{array}$ \\
\hline Arenicola marina (adult) & $354 \pm 58$ & & Schöttler et al., 1990 \\
\hline Nephtys hombergi & $117 \pm 39$ & & Arndt \& Schiedek, 1997 \\
\hline
\end{tabular}

1972). In Marenzelleria spp. the glycogen content is not that high and differs between North Sea and Baltic populations (Table 1). Although its concentration is somewhat lower in M. cf. wireni, both species utilised nearly the same amount of glycogen during $24 \mathrm{~h}$ of anoxia (Schiedek, 1997a).

In juvenile Arenicola marina and adult Scoloplos armiger the glycogen pool is also relatively small (Table 1), but like $M$. cf. wireni, both worms are able to maintain a fully aerobic metabolism down to an oxygen partial pressure below $3 \mathrm{kPa}$. Furthermore, all three polychaetes have in common only moderate resistance to anoxia (Schöttler \& Grieshaber, 1988; Schiedek \& Schöttler, 1990; Schiedek, 1997a). Higher amounts of glycogen are present in $H$. diversicolor and adult $A$. marina (Table 1). These polychaetes are known to sustain anoxia for several days (Schöttler \& Bennet, 1991).

The glycogen pool of the free-living, burrowing predator, N. hombergi, is also relatively low. In contrast to $M$. cf. wireni and other marine polychaetes, the phosphagen store (phosphoglycocyamine) of this mobile worm is remarkably high (about $160 \mu \mathrm{mol}$ $\mathrm{g}^{-1}$ dry wt). During environmental stress it is used as the primary energy source (Arndt \& Schiedek, 1997). The phosphagen pool (phospho-L-arginine) in $M$. cf. wireni amounts to $25 \mu \mathrm{mol} \mathrm{g}{ }^{-1}$ dry wt (Schiedek, 1997a). A similar value, but a different compound (phosphotaurocyamine), is given in juvenile A. marina (Schiedek \& Schöttler, 1990). whereas in $S$. armiger the phosphagen content (phosphoglycocyamine and phosphocreatine) amounts to about $80 \mu \mathrm{mol} \mathrm{g}^{-1}$ dry wt (Schöttler \& Grieshaber, 1988).

\section{INFLUENCE OF HYDROGEN SULPHIDE}

Beneath the oxidised surface layer of almost all marine sediments a sulphide-containing reduced zone occurs which results from dissimilatory sulphate reduction (Jørgensen \& Fenchel, 1974). Sulphide concentrations in the sediment pore water of marine habitats range from a few up to several millimoles per litre (Bagarinao, 1992) depending upon the sediment structure and the organic matter content. In the Tay estuary, for instance, sulphide concentrations in the pore water range from 0.05 to $0.5 \mathrm{mmol} \mathrm{l}^{-1}$ during low tide (Schiedek et al., 1997). For estuarine benthic species this might not really be a problem, since low oxygen concentrations require a switch from aerobic to anaerobic metabolism irrespective of the presence of hydrogen sulphide. However, in the pres- 


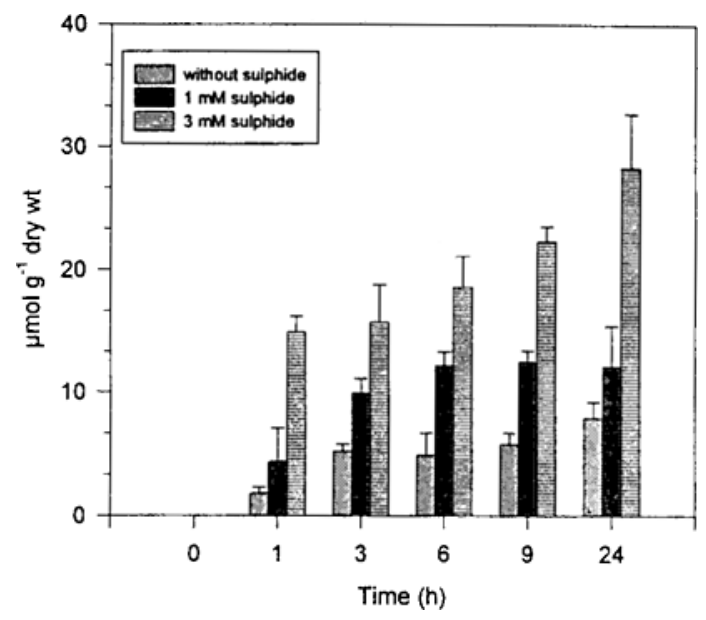

Fig. 4. Succinate content ( $\mu \mathrm{mol} \mathrm{g}^{-1}$ dry wt) after hypoxic incubation $(0-24 \mathrm{~h})$ in the absence or presence of hydrogen sulphide. Mean $\pm \operatorname{SEM}, n=4$

ence of sulphide this switch already occurs at a higher oxygen partial pressure depending upon the ambient sulphide concentration, as studies on A. marina have revealed (Völkel \& Grieshaber, 1992, 1994). Relying on anaerobic metabolism does not provide complete protection against this harmful toxin. Sulphide exposure often results in reduced survival as various studies have shown (for review see Vismann, 1991; Diaz \& Rosenberg, 1995).

When experimentally exposed to hydrogen sulphide, $M$. cf. wireni is able to cope with clearly higher sulphide concentrations (up to $3 \mathrm{mmol} \mathrm{l}^{-1}$ ) than other marine polychaetes (Schiedek et al., 1997). Nevertheless, survival is already reduced in the presence of $1 \mathrm{mmol}$ sulphide $\mathrm{l}^{-1}$ from about 6.5 days ( $\mathrm{LT}_{50,}$, severe hypoxia) to 4.5 days $\left(\mathrm{LT}_{50}\right.$ $1 \mathrm{mM}$ sulphide). Furthermore, the pattern of end products of anaerobic energy metabolism changes. In the presence of sulphide $\left(1 \mathrm{mmol} \mathrm{l}^{-1}\right)$ succinate accumulation is already increased (Fig. 4), whereas anaerobic energy production via glycolysis (end product octopine) is not significantly higher (Schiedek et al., 1997). Enhanced octopine accumulation (up to $23 \mu \mathrm{mol} \mathrm{\textrm {g } ^ { - 1 }}$ dry wt) within $24 \mathrm{~h}$ of severe hypoxia only accurs when the worms were exposed to a sulphide concentration of $3 \mathrm{mmol} \mathrm{l}^{-1}$ (Schiedek et al., 1997). Under these conditions, not only octopine is accumulated to a significantly higher degree, but also succinate (Fig. 4 ). Owing to technical problems it was not possible to determine the short-chain fatty acids, propionate and acetate, in the "sulphide experiments". Therefore, an overall energy balance cannot be calculated. The high succinate content after only $1 \mathrm{~h}$ of sulphide exposure, however, suggests an enhanced anaerobic metabolism in the presence of a higher sulphide concentration $\left(3 \mathrm{mmol} \mathrm{l}^{-1}\right)$, probably to provide energy in order to escape from this hostile environment. The elevated production of octopine would underline this, in particular, since it is known that marine invertebrates accumulate octopine when performing extended muscle activity until exhaustion (Grieshaber et al., 1994).

Not only $M$. cf. wireni is able to cope with enhanced sulphide concentrations, but also $M$. viridis; however, in the latter the increase in succinate accumulation is less pro- 
nounced under these conditions (Schiedek, 1997b). Furthermore, survival is not reduced in the presence of hydrogen sulphide at comparable concentrations (Bochert et al., 1997). This suggests that the sibling species gradually differ in their metabolic responses. The metabolic capabilities of $M$. cf. wireni appear to be more limited when exposed to hydrogen sulphide in higher concentrations $\left(>1 \mathrm{mmol} \mathrm{l}^{-1}\right)$, but further experiments are needed to prove this hypothesis.

As already mentioned above, in the Tay estuary sulphide occurs only in moderate concentrations (up to $0.5 \mathrm{mmol} \mathrm{l}^{-1}$ ), whereas in the coastal areas of the Baltic (Darss Zingst bodden chain), it reaches values of about $4.2 \mathrm{mmol}^{-1}$ (Bochert et al., 1997). This provides further evidence that the sulphide concentrations in the sediment might have an influence on successful settlement and, therefore, on the distribution pattern of the two sibling Marenzelleria species.

The harmful effect of sulphide is mainly due to its inhibition of the cytochrome $c$ oxidase by reversibly binding at the haeme site to cytochrome $a a_{3}$, the last complex of the respiratory electron transport chain (National Research Council, 1979). In order to deal with this toxic substance, sulphide needs to be oxidised to a less or non-toxic sulphur compound. In many species the favoured oxidation product is thiosulphate (Grieshaber \& Völkel, 1998). In M. cf. wireni thiosulphate is also present after sulphide exposure even during severe hypoxia (Schiedek et al., 1997). It is detectable directly after the onset of hypoxia and amounts to about $7 \mu \mathrm{mol} \mathrm{g}^{-1}$ dry wt, a value which is relatively low when compared to $M$. viridis or other polychaetes. In $M$. viridis about $30 \mu \mathrm{mol} \mathrm{g}^{-1}$ dry wt appears in the worms after $6 \mathrm{~h}$ of sulphide exposure (Schiedek, 1997b). A clearly higher content is already present in the muscle tissue of the lugworm A. marina after exposure to $0.1 \mathrm{mmol} \mathrm{l}^{-1}$ sulphide and anoxia (Grieshaber et al., 1995). The reasons for the lower thiosulphate concentrations in $M$. cf. wireni as compared to A. marina are not known at present.

\section{CONCLUDING REMARKS}

The newly established polychaete worm, M. cf. wireni, is capable of coping with different kinds of environmental stress (Table 2). Regarding the metabolic responses to variations in salinity or exposure to hypoxia, no significant differences between $M$. cf. wireni and other, indigenous species have been found. Nevertheless, with respect to sulphide tolerance the neozoan spionid appears to be better adapted than other, native

Table 2. Metabolic features of Marenzelleria ssp. - an overview

\begin{tabular}{|lll|}
\hline & Marenzelleria cf. wireni & Marenzelleria viridis \\
\hline Salinity tolerance & $32-0.5 \%$ o & $30-0.5 \%$ \\
Main free amino acid (salinity $15 \%$ ) & Glycine & Alanine \\
Start anaerobic energy production & $<3 \mathrm{kPa}$ & $<3 \mathrm{kPa}$ \\
Glycolysis & \pm & \pm \\
Succinate-pathway & ++ & ++ \\
$\mathrm{H}_{2}$ S tolerance & Up to $3 \mathrm{mmol} \mathrm{I}-1$ & Up to $3 \mathrm{mmol}^{-1}$ \\
$\mathrm{H}_{2} \mathrm{~S}$ detoxification & + & + \\
\hline
\end{tabular}


polychaetes, e.g. $H$. diversicolor. When compared to the sibling species, $M$. viridis, which appeared at the same time in European waters and predominantly inhabits the coastal inlets of the Baltic Sea in high numbers, the metabolic capabilities of $M$. cf. wireni seem to be more limited when exposed to higher hydrogen sulphide concentrations $(\geq 1 \mathrm{mmol}$ $\mathrm{l}^{-1}$ ). The shift in the importance of different free amino acids after acclimation to salinities above $10 \%$ suggests some differences in the osmotic adaptation between the two sibling species. However, further experiments are needed to prove this hypothesis.

Acknowledgements. The study was supported by the Federal Ministry for Education, Science, Research and Technology, Grant No. 03F0031D and DYSMON 03F0123E.

\section{LITERATURE CITED}

Arndt, C. \& Schiedek, D., 1997. Nephtys hombergii, a free-living predator in marine sediments: energy production under environmental stress. Mar. Biol. 129, 643-650.

Atkins, S. M., Jones, A. M. \& Garwood, P. R., 1987. The ecology and reproduction cycle of a population of Marenzelleria viridis (Annelida: Polychaeta: Spionidae) in the Tay Estuary. Proc. R. Soc. Edinb. 92B, 311-322.

Bagarinao, T., 1992. Sulfide as an environmental factor and toxicant: tolerance and adaptations in aquatic organisms. Aquat. Toxicol. 24, 21-62.

Bastrop, R., Röhner, M., Sturmbauer, M. \& Jürss, K., 1997. Where did Marenzelleria spp. (Polychaeta:Spionidael in Europe come from? Aquat. Ecol. 31, 119-136.

Bick, A. \& Burckhardt, R., 1989. Erstnachweis von Marenzelleria viridis (Poiychaeta, Spionidae) für den Ostseeraum, mit einem Bestimmungsschlüssel der Spioniden der Ostsee. Mitt. Zool. Mus. Berl. 65, 237-247.

Bick, A. \& Zettler, M. L., 1997. On the identity and distribution of two species of Marenzelleria (Polychaeta: Spionidae) in Europe and North Americá. Aquat. Ecol. 31, 137-148.

Bochert, A., Richard, D. \& Bochert, R., 1997. Marenzelleria cf. viridis and the sulphide regime. Aquat. Ecol. 31, 223-231

Bochert, R., 1997. Marenzelleria viridis (Polychaeta: Spionidae): a review of its reproduction. Aquat. Ecol. 31, 163-175.

De Zwaan, A. \& Zandee, D. I., 1972. Body distribution and seasonal changes in the glycogen content of the common sea mussel Mytilus edulis. Comp. Biochem. Physiol., 43A, 53-58.

Diaz, R. J. \& Rosenberg, R., 1995. Marine benthic hypoxia: a review of its ecological effects and the behavioural responses of benthic macrofauna. In: Oceanography and marine biology, an annual review, 33. Ed. by A. D. Ansell, R. N. Gibson \& M. Barnes. UCL Press, London 245-303.

Duchateau-Bosson, G. H. \& Florkin, M., 1961. Change in intracellular concentration of free amino acids as a factor of euryhalinity in the crayfish Astacus astacus. Comp. Biochem. Physiol. 3 , 245-249.

Elliot, M. \& Kingston, P. F., 1987. The sublittoral benthic fauna of the estuary Firth of Forth, Scotland. Proc. R. Soc. Edinburgh 93B, 449-466.

Essink, K. \& Kleef, H. L., 1993. Distribution and life cycle of the North American spionid polychaete Marenzelleria viridis (Verrill, 1873) in the Ems estuary. Neth. J. Aquat. Ecol. 27, 237-246.

Essink, K., Eppinga, J. \& Dekker, R., 1998. Long-term changes (1977-1994) in intertidal macrozoobenthos of the Dollard (Ems estuary) and effects of introduction of the North American spionid polychaete Marenzelleria cf. wireni. Senckenb. Marit 28, 211-225.

Florkin, M., 1956. Vergleichende Betrachtung des stationären Zustandes der nicht eiweissgebundenen Aminosäuren in Tieren. Colloq. Ges. Physiol. Chem. 6, 62-99.

Florkin, M., 1962. La régulation isosmotique intracellulaire chez les invertébrés marins euryhalins. Bull. Acad. Belg. Cl. Sci. 48,687-694.

Gilles, R., 1987. Volume regulation in cells of euryhaline invertebrates. In: Cell volume control: fundamental and comparative aspects in animal cells. Ed. by A. Kleinzeller. Academic Press, London, 205-247. 
Grieshaber, M. K. \& Kreutzer, U., 1986. Opine formation in marine invertebrates. Zool. Beitr. N.F. 30, 205-229.

Grieshaber, M. K. \& Völkel, S., 1998. Animal adaptations for tolerance and exploitation of poisonous sulfide. Annu. Rev. Physiol. 60, 33-53.

Grieshaber, M., Hardewig, I., Kreutzer, U. \& Pörtner, H.-O., 1994. Physiological and metabolic responses to hypoxia in invertebrates. Rev. Physiol. Biochem. Pharmacol. 125, 44-147.

Grieshaber, M. K., Hauschild, K., Sommer A. \& Völkel, S. 1995. Anaerobiosis and sulphobiosis in the lugworm, Arenicola marina L. In: Biology and ecology of shallow coastal waters. Ed. by A. Eleftheriou, A. D. Ansell, C, H. Smith. Olsen \& Olsen, Fredensborg, 131-137.

Hohendorf, K., 1963. Der Einfluß der Temperatur auf die Salzgehaltstoleranz und Osmoregulation von Nereis diversicolor O.F. Muell. Kieler Meeresforsch. 19, 196-218.

Hülsmann, R., Osinsky, R., Schiedek, D. \& Schöttler, U., 1991. The importance of proline metabolism for adaptation to low salinity in Nereis diversicolor (Polychaeta). Verh. Dtsch. Zool. Ges. 84,411 .

Jørgensen, B. B.\&. Fenchel, T., 1974. The sulfur cycle of a marine sediment model system. Mar. Biol. 24, 189-201.

König, M., Powell, E. N. \& Kaschau, M. R., 1981. The effects of salinity change on the free amino acid pools of two Nereid polychaetes, Neanthes succinea and Leonereis culveri. Comp. Biochem. Physiol. 70A, 631-637.

National Research Council, 1979. Hydrogen sulfide. University Park Press, Baltimore, $183 \mathrm{pp}$.

Oglesby, L. C. 1978. Salt and water balance. In: Physiology of annelids. Ed. by P. J. Mill. Academic Press, London, 555-658.

Schiedek, D., 1997a. Marenzelleria viridis (Verrill 1873) (Polychaeta), a new benthic species within European coastal waters. Some metabolic features. J. Exp. Mar. Biol. Ecol. 211, 85-101.

Schiedek, D., 1997b. Marenzelleria cf. viridis (Polychaeta, Spionidae) - ecophysiological adaptations to a life in the coastal waters of the Baltic. Aquat. Ecol. 31, 199-210.

Schiedek, D. \& Schöttler, U., 1989. Mechanisms of adaptations to hyposmotic conditions: investigations on polychaetes from the intertidal. Verh. Dtsch. Zool. Ges. 82, 411.

Schiedek, D. \& Schöttler, U., 1990. The energy production of juvenile Arenicola marina (Polychaeta) under anoxic and hypoxic conditions. Helgoländer Meeresunters. 44, 135-145.

Schiedek, D. \& Schöttler, U., 1991. The influence of freshwater run-off on the population density of juvenile Arenicola marina (Polychaeta). In: Estuaries and coasts: spatial and temporal intercomparisons. Ed. by M. Elliott \& J.-P. Ducrotoy. Proc. ECSA 19, Caen 1989. Olsen \& Olsen, Fredensborg, Denmark, 195-200.

Schiedek, D., Vogan, C., Hardege, J. \& Bentley, M., 1997. Marenzelleria cf. wireni (Polychaeta, Spionidae) from the Tay estuary. Metabolic response to severe hypoxia and hydrogen sulphide. Aquat. Ecol. 31, 211-222.

Schöttler, U. \& Bennet, E. M., 1991. Annelids. In: Metazoan life without oxygen. Ed. by C. Bryant. Chapman and Hall, London, 165-185.

Schöttler, U. \& Grieshaber, M. K., 1988. Adaptation of the polychaete worm Scoloplos armiger to hypoxic conditions. Mar. Biol. 99, 215-222.

Schöttler, U, Daniels, D. \& Zapf, K., 1990. Influence of anoxia on adaptation of euryhaline polychaetes to hyposmotic conditions. Mar. Biol. 104, 443-451.

Vismann, B., 1991. Sulfide tolerance: physiological mechanisms and ecological implications. Ophelia $34,1-27$.

Völkel, S. \&. Grieshaber, M. K., 1992. Mechanisms of sulfide tolerance in the peanut worm Sipunculus nudus (Sipunculida) and the lugworm Arenicola marina (Polychaeta). J. Comp. Physiol. $162 B, 469-477$.

Völkel, S. \& Grieshaber, M. K., 1994. Oxygen-dependent sulfide detoxification in the lugworm Arenicola marina. Mar. Biol. 118, 137-147.

Williams, D. J. \& West, J. R., 1975. Salinity distribution in the Tay estuary. Proc. R. Soc. Edinb. 75B, 29-39.

Zettler, M., 1997. Bibliography on the genus Marenzelleria and its geographical distribution, principal topics and nomenclature. Aquat. Ecol. 31, 233-258. 